\title{
Snow Amount in Relation to Streamflow and Herbage Production in Western Colorado
}

\section{ERNEST C. FRANK}

Highlight: A $10 \%$ increase in peak snowpack, due to cloud seeding or natural events, is partly returned as runoff but has little, if any, immediate effect on the productivity and use of mountain grasslands.

Public concern over the consequences of augmenting the mountain snowpack by cloud seeding has set researchers to reworking data in an effort to determine the influence of modest increases of snow on the environment. One such set of precipitation, runoff, and vegetative production data from the Black Mesa Experimental Range has been analyzed statistically to quantitatively define relationships of peak snowpack to hydrologic characteristics and herbage production.

The experimental area is located west of Gunnison, Colo., on National Forest land at an elevation of 9,800 ft. The vegetative cover is broadly classified as aspen, spruce-fir, and herbaceous. The last, commonly referred to as Thurber fescue grassland, comprises approximately $50 \%$ of the area. A mixed grassweed complex occupies the largest area within the herbaceous type. Needlegrasses (Stipa lettermanii Vasey and S. columbiana Macoun) and Idaho fescue (Festuca idahoensis Elmer) are frequently found components. Hummocky areas, termed mima mounds, support a variety of cover types. On some, Thurber fescue (Festuca thurberi Vasey) predominates; on others, hairy goldaster (Chrysopsis villosa [Pursh] Nutt. ex DC) is the major species. These small parks are grazed extensively by cattle in summer.

The author is associate hydrologist at the Rocky Mountain Forest and Range Experiment Station, Forest Service, U. S. Department of Agriculture. Central headquarters of the Station is maintained at Fort Collins, Colo. in cooperation with Colorado State University. Research reported here was conducted and partly financed in cooperation with the Office of Atmospheric Water Resources, Bureau of Reclamation, U. S. Department of the Interior. Manuscript received May 9, 1972.

\section{Methods}

Records for this paper were obtained from long-term grazing and watershed studies on Black Mesa. The studies have been generally described in a progress report (U. S. Forest Service, 1959), and certain preliminary findings were reported by Paulsen (1969). Additional records are on file at the Rocky Mountain Station.

Since 1954, two fenced pastures have been sampled each year to estimate total production of grasses, forbs, and shrubs. Thirty transects were established per pasture in the herbaceous type. Three $2.5 \mathrm{ft}^{2}$ plots per 50-ft transect were used to estimate production by the weight estimate method (Pechanec and Pickford, 1937), usually late in July.

Five snow courses were established on three experimental watersheds at Black Mesa in 1956. One or more of these were sampled two or more times in the spring each year, usually near April 1 and May 1. Peak snowpack data are based on the average of the five snow courses. There is some chance peak snowpack was missed because of the infrequent sample, but the five-course-average peak and the onecourse peak agree as to date in all but one year.

Runoff data, including total and peak flow, were measured by a $90^{\circ} \mathrm{V}$-notch weir on watershed 6 . The snow courses cover an area greater than this watershed and are only an index of the precipitation received; even so, they are highly correlated with water yield.

Herbage production data are from two moderately grazed pastures, 1 and 6 (Fig. 1). Watershed 6 makes up $69 \%$ of the area and contains 22 of the 30 transects making up pasture 6. Pasture 1 is approximately 2 miles from the precipitationmeasuring area.
Results

Several linear regression equations were computed from the basic data (Table 1), and the correlation coefficients were tested for significance. As is commonly found, runoff parameters correlated well with the precipitation variable. The corrclation coefficient " $r$ " is 0.94 for the peak snowpack-water yield relationship. For the sample size of 13 years, " $r$ " is significant at the $1 \%$ level.

The steep slope of the peak snowpackwater yield regression indicates a substantial return in snowmelt runoff for any additions to peak snowpack.

The regression equation, $\mathrm{Y}=0.73 \mathrm{X}-$ 6.4 ( $\mathrm{Y}$ is water yield in inches and $\mathrm{X}$ peak snowpack water equivalent in inches), was used to predict the increase in water yield expected from a $10 \%$ increase in peak snowpack by substituting $\mathrm{X}$ and $\mathrm{X}+$ $0.10 \mathrm{X}$ in the equation. Subtracting the first yield from the second gives the expected increase. At the mean annual peak snowpack a $10 \%$ addition (1.8 inches water equivalent) results in a 1.4-inch increase in water yield; however, due to the large standard error of estimates (1.4 inches), the confidence interval at the mean is \pm 0.9 inch of runoff for an average year.

Similarly the increase in runoff for a $10 \%$ increase in peak snowpacks ranging from 10 to 30 inches was computed (Fig. 2). For this range of data, the confidence interval is \pm 1.5 and \pm 2.3 inches at the minimum and maximum annual peak snowpack.

Peak discharge and peak snowpack are also highly correlated $(r=0.82$, significant at $16.1 \%$ level). Using the prediction equation, $\mathrm{Y}=1.11 \mathrm{X}-5.0$, as outlined for water yield a $10 \%$ increase in mean snow water equivalent yields a predicted increase of approximately $2 \mathrm{ft}^{3} /$ second 


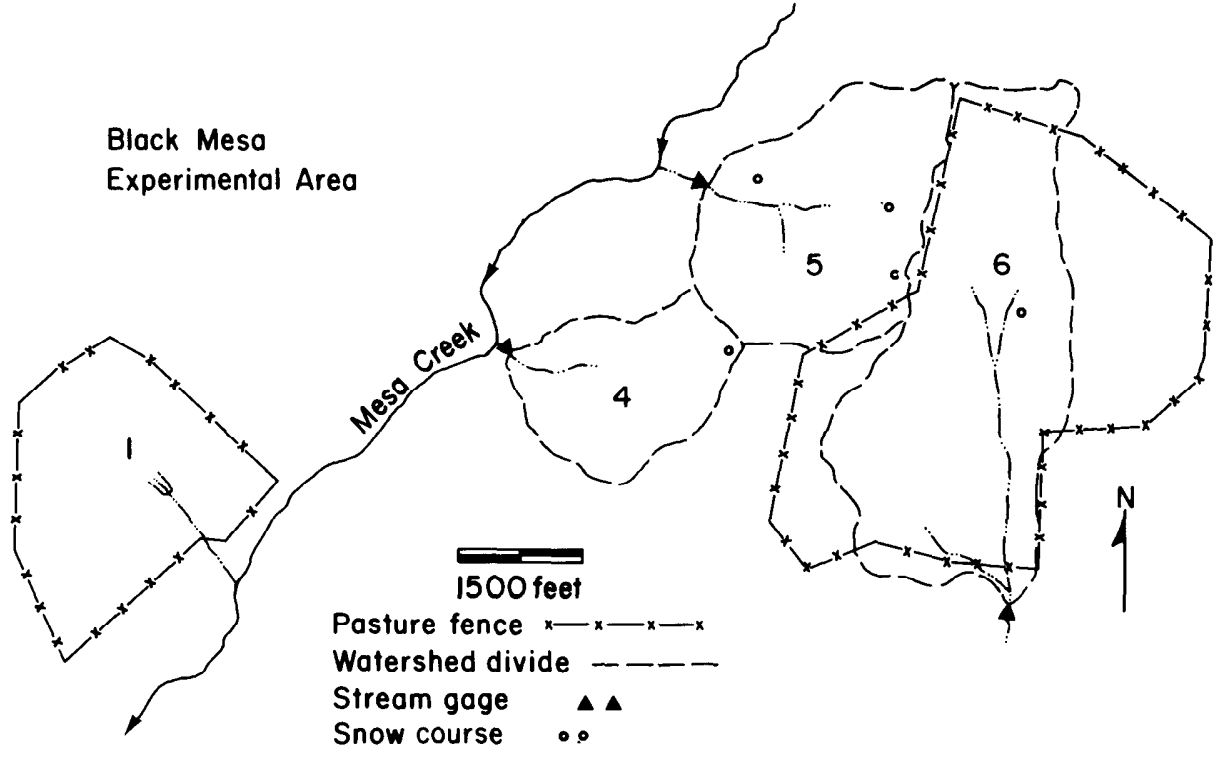

Fig. 1. Black Mesa Experimental Area.

per square mile (csm) in the mean peak flow of $15 \mathrm{csm}$ (Fig. 3). The confidence interval at maximum peak pack is $\pm 7 \mathrm{csm}$ and at minimum $\pm 4 \mathrm{csm}$.

The correlation between (1) peak snowpack and (2) days from the start of runoff until the day of peak discharge is not significant until the probability level exceeds $50 \%$. Another snow-duration analysis produced a significant correlation between peak snowpack and days from start of runoff until snow disappears from the herbaceous and aspen types. Snow disappearance was estimated from photographs, cessation of flow on watershed 5 , and the day-to-day observations of the range technician working at Black Mesa. April 26 was the average start of runoff. Snow cover then lasted another 16 to 40 days. For 6 of the 10 years, snow cover lasted within \pm 2 days of the mean duration of 26 days. A $10 \%$ increase in mean pack would increase the duration of snow cover 1.5 days.

Relationships between peak snowpack and herbage production do not reach significance at the $5 \%$ probability level. A linear regression fitted to the current year's peak snowpack and that summer's grass production does show a weak negative correlation, however. While the correlation coefficient is significant at the $14 \%$ level ( 1 in 7 chance instead of the traditional 1 in 20 ), only $17 \%$ of grass production variance is attributable to peak pack. The regression equation predicts a $25 \mathrm{lb}$./acre decrease in grass production for a $10 \%$ increase in peak snowpack. This is less than the "15\% of the mean" criterion used to estimate grass production, and within the confidence interval at mean grass production on the regression line. The linear analysis shows vious year and the current year's grass production are plotted, they appear to be positively correlated, but the relationship is not significant.

\section{Discussion}

On a mountain grassland-timber range of the mesa country on the western slope of Colorado, peak snowpack correlates well with water yield and peak discharge. Snow cover lasts almost a month, once spring runoff starts late in April. Increasing the snow precipitation input by $10 \%$ would lengthen the duration of snow cover less than 2 days.

Relationships of herbage production to peak snow water equivalent were not significant at the 5\% level. Grasses have frequently been observed to be greening up under the snow cover. According to Paulsen (1969), rapid herbage growth begins soon after snowmelt, and reaches its maximum 6 to 8 weeks later. Heavy snow may delay peak production until August, but seeds ripen by September and the grasses and forbs are capable of completing their cycle in all but the most

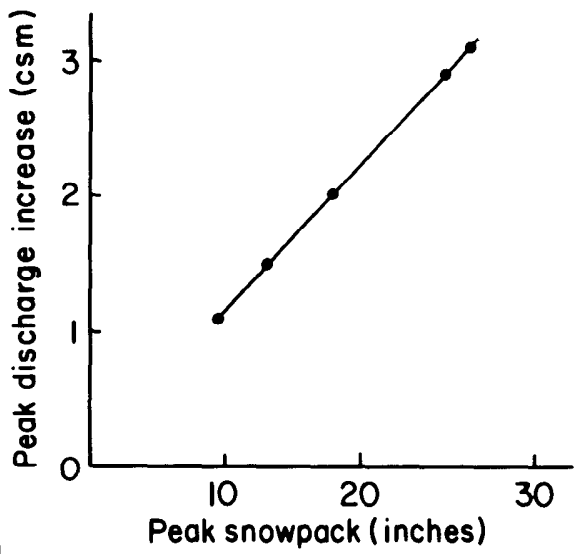

Fig. 3. Predicted increase in peak discharge from a $10 \%$ increase in peak snowpack.

Table 1. Hydrologic and range production (lb./acre) data.

\begin{tabular}{lcccccc}
\hline \hline Year & $\begin{array}{c}\text { Peak snowpack } \\
\text { water equivalent, } \\
\text { (inches) }\end{array}$ & $\begin{array}{c}\text { Runoff } \\
\text { (inches) }\end{array}$ & $\begin{array}{c}\text { Peak dis- } \\
\text { charge } \\
\text { (c.s.m.) }\end{array}$ & $\begin{array}{c}\text { Duration of } \\
\text { snow (days) }\end{array}$ & \multicolumn{2}{c}{ Production 1} \\
\hline 1956 & 16.1 & 4.8 & 12 & - & 512 & Grasses \\
1957 & 28.2 & 16.2 & 27 & Forbs \\
1958 & 26.5 & 13.0 & 22 & 40 & 529 & 865 \\
1959 & 13.3 & 3.3 & 10 & 25 & 584 & 826 \\
1960 & 17.6 & 6.2 & 25 & 16 & 586 & 701 \\
1961 & 13.8 & 3.3 & 7 & 32 & 484 & 677 \\
1962 & 20.2 & 7.9 & 15 & 22 & 622 & 1069 \\
1963 & 13.9 & 1.7 & 5 & 27 & 751 & 814 \\
1964 & 17.9 & 6.2 & 19 & 24 & 683 & 683 \\
1965 & 20.2 & 8.6 & 18 & 25 & 510 & 546 \\
1966 & 13.8 & 6.3 & 14 & 26 & 828 & 912 \\
1967 & 9.7 & 2.0 & 4 & 25 & 1032 & - \\
1968 & 22.5 & 7.9 & 17 & - & 955 & - \\
1969 & 18.2 & - & - & - & 563 & - \\
\hline
\end{tabular}

${ }_{1}^{1}$ Paulsen (1969) for 1956-65 data; $1966-69$ data on file at Rocky Mountain Forest and Range Experiment Station, Project RM-1701. 
unusual years, where very heavy spring snowpacks are followed by early fall frost. In spring, the moving of cattle up to their summer range is not restricted by snow cover, but by the growth stage of poisonous larkspurs (Delphinium sp.). Duration of snow cover could influence the phenology of larkspurs, but data are not available from Black Mesa to test this hypothesis.

These observations and analyses indicate that a $10 \%$ increase in snowpack due to cloud seeding would have little, if any, immediate effect on the productivity and use of mountain grasslands.

\section{Literature Cited}

Paulsen, Harold A., Jr. 1969. Forage values on a mountain grassland-aspen range in western Colorado. J. Range Manage. 22: 102-107.

Pechanec, J. F., and G. D. Pickford. 1937. A weight estimate method for the determination of range or pasture production. J. Am. Soc. Agron. 29:894-904.

U. S. Forest Service. 1959. Research on Black Mesa--a progress report. U. S. Dep. Agr., Forest Serv., Rocky Mt. Forest and Range Exp. Sta. Sta. Pap. 41.18 p. 